\title{
PERBANDINGAN SUMBER PAKAN DAN STRATEGI PEMBERIAN PAKAN Apis cerana DENGAN APIDAE LAINNYA: A REVIEW.
}

\author{
Rhavy Ferdyan ${ }^{1)}$, Ramadhan Sumarmin ${ }^{2)}$, Dwi Hilda Putri ${ }^{3)}$ \\ ${ }_{1,2), 3)}$ Program Studi Biologi, Universitas Negeri Padang \\ Email $^{1)}$ :rhavyferdyan@unp.ac.id \\ Email $^{2}$ : ramadhan_sum@fmipa.unp.ac.id \\ Email $^{3)}$ :dwi_hildaputri@yahoo.com
}

\begin{abstract}
ABSTRAK: Apis cerana yang sering disebut dengan lebah madu telah menyebar mulai dari Afghanistan, China, Jepang, hingga Indonesia. Distribusi tersebut tidak lepas dari kemampuan Apis cerana untuk bertahan hidup dengan membutuhkan makanan. Serbuk sari dan nektar merupakan sumber makanan utama Apis cerana dalam mempertahankan kehidupan. Apis cerana banyak dibudidayakan oleh masyarakat dengan potensi yang dimilikinya. Artikel ini bertujuan untuk mendeskripsikan lebih detail tentang tanaman hijauan dari Apis cerana dan bagaimana strategi pemberian pakan lebah madu dirangkai dari beberapa penelitian di berbagai daerah, baik di Indonesia maupun di luar Indonesia serta membandingkan aktivitas keseharian tersebut dengan Apidae lainnya. Pembahasan difokuskan pada analisis komparatif aktivitas keseharian Apis cerana dengan Apidae lainnya untuk melihat keunikan Apis cerana yang menjadi faktor banyaknya lebah yang dibudidayakan.
\end{abstract}

Kata kunci: Aktivitas, Apis cerana, Pakan, Strategi pemberian pakan, Fotoperiodisme

ABSTRACT: Apis cerana, which is often known as honey bee, has spread from Afghanistan, China, Japan, to Indonesia. This distribution cannot be separated from Apis cerana's ability to survive by needing food. Pollen and nectar are the main food sources for Apis cerana in maintaining life. Apis cerana is widely cultivated by the community with its potential. This article aims to describe in more detail about the forage plants from Apis cerana and how the feeding strategies of honey bees were assembled from several studies in various regions, both in Indonesia and outside Indonesia as well as comparing these daily activities with other Apidae. The discussion is focused on the comparative analysis of the daily activities of Apis cerana with other Apidae to see the uniqueness of Apis cerana which is a factor in the number of bees being cultivated.

Keywords: Activity, Apis cerana, Feed, Feeding strategy, Photoperiodism

\section{PENDAHULUAN}

Apis cerana yang sering juga dikenal sebagai lebah madu sudah menyebar mulai dari Afghanistan, China, Jepang, hingga Indonesia. Persebaran tersebut tidak lepas dari kemampuan Apis cerana dalam bertahan hidup dengan membutuhkan makanan. Lebah madu memiliki sumber pakan dari tanaman antara lain tanaman buah, tanaman sayuran, tanaman industri, tanaman hutan. Makanan tersebut berupa nektar atau tepung sari bunga (polen) (Jayuli, Junus, \& Nursita, 2018). Polen merupakan tepung sari dari bunga yang nantinya berguna untuk tanaman pada proses penyerbukan. Polen didapatkan dari bunga pada bagian kepala sari (anther) yang bertindak sebagai 
kelamin jantan tumbuhan. Polen mempunyai perbedaan pada bentuk dan warna yang ditentukan oleh varietas tumbuhan. Kandungan protein pada polen tergantung dari jenis tumbuhan penghasil polen. Produksi madu yang dihasilkan oleh lebah madu dipengaruhi oleh nektar dan pollen yang dihasilan oleh bunga dari tanaman-tanaman yang dikunjungi lebah.

Sarang yang memiliki ketersediaan nektar akan merangsang pertumbuhan koloni lebah yang lebih baik lagi, seperti dalam hal membuat sarang baru dan dalam menghasilkan telur. Sedangkan adanya pollen yang cukup di sarang, akan meningkatkan kualitas koloni lebah, serta relative panjangnya hidup lebah. Manajemen koloni lebah sangat tergantung kepada kesetraan nutrisi lebah tersebut, kurangnya salah satu atau keduanya dari unsur pakan lebah atau jumlahnya sedikit secraa langsung akan membuat kehidupan lebah terganggu, dan mengakibatkan lebah bisa hijrah, koloni mudah terserang hama/penyakit, lama harapan hidup lebah pendek dan organ tubuh lebah menjadi kurang lengkap (Hasanudi, 2014).

Strategi mencari makan yang ada pada lebah memiliki keunikan. Hal ini dapat dilihat dengan terdapatnya struktur koloni pada lebah sebagai serangga sosial. Lebah pekerja merupakan lebah yang sangat berperan banyak dalam hal mencari sumber makanan, dan mengangkutnya kedalam sarang. Tujuan dari Lebah pekerja menyambangi bunga untuk mengambil nektar dan serbuk sari (Raju \& Ezardanama, 2002), yang digunakan sebagai kebutuhan nutrisi (Van Rijn, Van Houten, \& Sabelis, 2002).

Penelitian mengenai ketersediaan makanan bagi Apis cerana berikut aktivitasnya dapat dilakukan dengan studi ekologi pada Apis cerana. Penelitian sebelumnya yang dilakukan di Desa Pagar Puding Kecamatan Tebo Ulu Kabupaten Tebo provinsi Jambi menunjukkan jenis pohon yang digunakan untuk bersarang, jenis tumbuhan berbunga yang dikunjungi lebah pekerja, dan kondisi lingkungan fisis. Familia tumbuhan yang terbanyak dikunjungi adalah familia Leguminoceae (Irsad, 2014).

Musim sangat mempengaruhi ketersediaan pakan, pada musim peghujan pollen dan nektar sangat terbatas jumlahnya di alam (Ariyanti, 2018). Hal ini tentu akan mempengaruhi aktivitas dari lebah untuk mendapatkan makanan. Kekurangan pakan yang terjadi, akan membuat lebah berpindah ke tempat yang memiliki pakan yang cukup.

Lebah madu sudah lama dikenal dan dibudidayakan, akan tetapi masih banyak keunikan-keunikan yang belum terkomparasikan. Masyarakat sudah lama juga melakukan budidaya terhadap Apis cerana dan mengambil banyak manfaat darinya. Akan tetapi masih ada beberapa tulisan yang mengakatakan Apis cerana kurang produktif dari kelompok lebah lainnya (yang tergolong Apidae) seperti Apis mellifera dan Apis dorsata.

Artikel ini bertujuan untuk melakukan review, membandingkan, merakit, serta memaparkan berbagai macam riset yang dilakukan tentang pakan dan strategi mencari makan dari Apis cerana dengan kelompok Apidae lainnya yang telah dilakukan pada berbagai wilayah baik di Indonesia maupun diluar Indonesia.

\section{METODE PENELITIAN}

2.1. Lebah pekerja (workers) sebagai pencari sumber makanan

Lebah pekerja (workers) merupakan lebah betina dengan organ 
reproduksi yang tidak berkembang, sehingga tidak menghasilkan telur. Lebah ini memiliki warna hitam dengan panjang tubuh 3-4 mm, panjang sayap sekitar $8 \mathrm{~mm}$, kaki belakang berkembang menjadi alat pembawa polen, tubuh berbulu dan tungkai berkait. Secara morfologi penelitian terbaru menjelaskan ada perbedaan morfologi lebah di daerah dataran tinggi dan dataran rendah yang meliputi berat badan dan bagian tubuh yang terdiri dari panjang probosis (PP), dan panjang femur tungkai belakang (PFB). Berat badan dan panjang femur tertinggi diperoleh pada lebah madu di dataran tinggi, sedangkan panjang probosis tertinggi diperoleh pada lebah madu alami di dataran rendah (Novita, Saepudin, \& Sutriyono, 2013). Lebah pekerja memiliki kemampuan mengkonversi unsur-unsur yang dikumpulkan dari tumbuhan, seperti resin, menjadi bahan untuk membangun sarang (wax dan propolis). Setelah mencari sumber makanan, maka lebah pekerja juga akan kembali ke sarang dan bertindak sebagai nurse. Selama di sarang, Lebah pekerja juga bertugas untuk membersihkan dan memelihara sarang, memelihara larva, dan menjaga sarang agar tetap bersih.

Kunjungan lebah pekerja pada bunga saat mencari makan menunjukkan perilaku tertentu yang dipengaruhi oleh kuantitas dan kualitas nektar pada bunga. Apis cerana sendiri mencari sumber makanan dimulai oleh lebah penjelajah (scout), setelah ditemukan lebah penjelajah memberikan sinyal kepada lebah pekerja melalui tarian lebah (bee dancing) sebagai penanda telah ditemukannya sumber makanan (Radloff et al., 2010). Produktivitas dari lebah sendiri dan bagaimana aktivitasnya di sarang tidak lepas dari peranan lebah pekerja. Sehingga dengan potensi ini lebah Apis cerana banyak dibudidayakan.

\subsection{Budidaya Apis cerana}

Masyarakat pedesaan sebagai peternak lebah, saat ini memilih untuk membudidayakan lebah madu $A$. cerana setelah $A$. mellifera, alasannya A. cerana memiliki kemampuan menyesuaikan diri yang lebih tinggi terhadap iklim tropis, tahan terhadap pengganggu da parasit, lebih agresif, dan diternakkan dengan cara yang sederhana. Lebah madu $A$. cerana dapat dipelihara baik di dataran tinggi, maupun dataran rendah (Novita et al., 2013). Apis cerana berpotensi tinggi untuk dikembangkan lebih lanjut karena lebih tahan terhadap penyakit (varhoa), mampu mengambil nektar bunga kecil disekitar namun memiliki produksi lebih rendah, hijrah tinggi dan agresif (Masnaly, Wadjdi, \& Puspitarini, 2021).

Semantara sumber lain ada yang mengatakan bahwa Apis cerana dinilai kurang produktif, sedikit ganas, dan membutuhkan upaya untuk membudidayakannya (Sembiring dan Dinata, 2020). Hal inilah menjadi pembahasan mendalam artikel kedepannya dimana melihat keunikan dan membandingkan aktivitas Apis cerana dengan lebah lainnya sebagai tolak ukur banyak atau tidaknya Apis cerana dibudidayakan.

\section{HASIL DAN PEMBAHASAN}

\subsection{Deskripsi Sumber Pakan dan Kunjungan Apis cerana pada tumbuhan}

Tanaman yang menjadi sumber makanan lebah madu adalah tanaman yang meliputi tanaman buah, tanaman sayuran, tanaman industri, tanaman hutan. Nektar dan pollen sangat berpengaruh dalam produksi madu yang akan dihasilkan oleh lebah madu 
yang berasal dari bunga dari tanamantanaman tersebut. Khususnya di Indonesia, ketersediaan tanaman pakan lebah madu di dipercayai cukup besar, akan tetapi informasi tentang tanamantanaman tersebut belum banyak tersedia, tanaman berbunga yang berkembang sangat baik di Indonesia sudah mencapai 25.000, spesies dan keragaman jenis tanaman yang sangat besar itu memungkinkan tersedianya nektar dan pollen sepanjang tahun.

Berdasarkan hasil penelitian mengenai sumber pakan Apis cerana, terdapat sumber pollen 20 jenis tanaman antara lain Arenga pinnata, Acacia mangium, Leucaena leucocephala, dan Cocos nucifera. Berdasarkan sumber nektar terdapat 24 jenis tanaman antara lain Carica papaya, Persea americana, Psidium guajava, dan Nephilium lappaceum (Mulyono, Susdiyanti, \& Supriono, 2018) (Jasmi, 2017). Penelitian lainnya yang dilakukan di Taman Nasiobal gunung Ciremai memperoleh hasil dimana terdapat 36 jenis tanaman yang menjadi sumber makanan, disana juga termasuk Acacia mangium dan Persea americana yang menjadi sumber polen dan nektar (Nurdin, 2019). Selain itu Apis cerana sendiri juga tidak visa terlepas dari ketertarikannya pada pakan tambahan. Faktor yang mempengaruhi lebah madu (Apis cerana) dalam beraktivitas mencari makan pakan tambahan yang disukai adalah faktor aroma dan kadar gula yang terkandung pada pakan tambahan (Nudastra, Artawan, \& Suryanti, 2016). Penelitian yang dilakukan di Australia, sumber pakan yang banyak dikunjungi oleh Apis cerana sendiri adalah Phyla canescens (Lippia) dan Cytisus scoparius yang sekaligus membantu penyebaran tumbuhan tersebut (Koetz, 2013).
Jika dibandingkan dengan Apis dorsata sebagai kelompok Apidae lainnya potensi sumber makanannya pun tidak jauh dari sumber makanan pada Apis cerana. Beberapa ragam potensial sebagai sumber nektar Apis dorsata adalah yaitu akasia, kelapa, karet, senduduk, dan durian (Pribadi, 2018) (Wibowo, Syafrizal, \& Susanto, 2017). Sedangkan dengan Apis mellifera juga tidak berbeda jauh berbeda yang menjadi sumber makanannya adalah tanaman hortikultura seperti kelapa (Cocos mufifera), jambu biji (Psidium guajava), dan rambutan (Nephelium lappaceum) (De Lima, Lamerkabel, \& Welerubun, 2019).

Pada dasarnya tidak ada yang sangat berbeda dalam hal sumber makanan dari Apis cerana dengan Apidae lainnya. Hal ini disebabkan oleh ketertarikan Apis cerana terhadap sumber makanan dalam hal warna bunga dan bau dari tanaman tersebut, begitu juga halnya dengan kelompok Apidae lainnya. Pada umumnya serangga lebih tertarik pada aroma dari tanaman yang akan dikunjungi (Hidayati, Sumarmin, \& Wati, 2010). Preferensi lebah madu terhadap jenis tanaman tertentu ditentukan oleh beberapa faktor seperti jumlah dan konsentrasi gula, aroma nektar, wangi bunga, warna bunga, jumlah dan kualitas serbuk sari, dan lain sebagainya. Selain itu juga ditentukan oleh matafaset yang ada pada lebah madu dalam melihat sumber makanan. Wrana bunga sangat menjadi penentu dalam mencari makan oleh lebah. Lebah madu memiliki empat dari sel visual yang mampu mersepon dengan baik warna kuning, hijau muda, dengan kisaran panjang gelombang $544 \mathrm{~nm}$, serta dua bagian yang mampu merespon dengan baik cahaya biru (463 nm), dan tidak mampu 
membedakan warna merah (Sarwono, 2001).

Hal yang membedakan yang ditemukan dari review ini adalah kelimpahan asam amino dari Apis cerana yang berbeda dengan Apis dorsata. Kelimpahan asam amino jauh lebih tinggi pada $A$. cerana daripada pada A. dorsata (Ghosh, Chuttong, Burgett, Meyer-Rochow, \& Jung, 2020). Hal ini sebenarnya tergantung kepada metabolisme tubuh masingmasing lebah yang berbeda sehingga kadar beberapa zat didalamnya juga jauh berbeda, sementara target sumber makanannya hampir sama.

Sementara itu, dalam hal kunjungan terhadap tanaman sumber pakan Apis cerana tidak jauh berbeda juga dengan Apidae lainnya dimana lebah mulai aktif mengunjungi pada pagi hari, menurun di siang hari, dan kembali meningkat keaktifannya pada sore hari (Mulyono et al., 2018). Frekuensi kunjungan juga tergantung pada ketersedian polen dan nektar pada tanaman.

Oleh karena itu, sumber pakan sebagai bahan dasar atau kebutuhan pokok dari Apis cerana mungkin tidak menjadi faktor yang utama dalam menentukan banyaknya lebah ini dibudidayakan atau tidak. Hal ini dikarenakan sumber pakan dan aktivitas kunjungannya tidak jauh berbeda dengan Apidae lainnya seperti Apis dorsata dan Apis mellifera.

\subsection{Foraging ranges pada Apis cerana}

Foraging ranges atau jarak mencari makan dari $A$. cerana bervariasi antar penelitian yang berbeda, tetapi umumnya lebah madu Apis lebih suka mencari makan dalam jarak 200 - $300 \mathrm{~m}$ dari sarang mereka. Setengah dari observasi yang dilakukan saat beberapa artikel diulas menunjukkan A. cerana mencari makan dalam jarak $250 \mathrm{~m}$ dari sarang, dan sebagian besar (95\%) A. cerana mencari makan di dalam 500 - 900 m. Jangkauan mencari makan maksimal yang dimiliki $1.500 \mathrm{~m}$ hingga $2.500 \mathrm{~m}$ (Koetz, 2013). Sebagai perbandingan, A. mellifera cenderung mencari makan pada jarak yang lebih jauh, dengan jarak maksimum lebih dari $10 \mathrm{~km}$ (Beekman \& Ratnieks, 2000). Sedangkan untuk Apis dorsata terbang dengan jarak $400 \mathrm{~m}$ dari sarang (Punchihewa, R. W. K., Koeniger, Kevan, \& Gadawski, 1985).

Foraging ranges ini dapat menjadi faktor yang harus dipertimbangkan oleh peternak lebah. Perbedaan yang ada pada Apis cerana dengan Apidae lainnya menentukan kualitas dari madu yang dihasilkan nantinya.

\subsection{Pengaruh Fotoperiodisme pada Strategi Makan Apis cerana}

Faktor yang sangat penting dan menentukan sekali pada pertumbuhan hewan adalah cahaya yang meliputi intensitas, spektrum warna dan fotoperiodisme. Fotoperiodisme merupakan respon fisiologis hewan terhadap rasio relatef mengenai lamanya penyinaran pada siang dan malam hari.

Fotoperiodsime bertindak sebagai rangsangan endogen nafsu makan dan pertumbuhan (Ariandana, 2010). Pembukaan bunga sebagai sumber makanan dan aktivitas lebah ,meningkat seiring kepada radiasi matahari yang cerah. A. cerana lebih dahulu memulai mencari makan daripada A. mellifera, karena secara adaptasinya $A$. cerana bergantung kepada suhu, intensitas cahaya dan tingkat radiasi matahari yang sedikit lebih rendah untuk memulai aktivitas mencari makan dari A. mellifera dan A. 
dorsata (Koetz, 2013). A. cerana paling aktif antara pukul 09.00 dan 11.30 ketika suhu $15,5-21^{\circ} \mathrm{C}$, sedangkan $A$. mellifera, yang paling aktif antara jam 11 pagi hingga 13.30 siang (Verma \& Dulta, 1986).

Dari perbadingan di atas dapat dilihat bahwa fotoperiodisme memiliki pengaruh yang sedikit berbeda antara A. cerana dengan Apidae lainnya, dimana $A$. cerana lebih memerlukan intensitas cahaya yang lebih rendah sehingga jadwal untuk terbang mencari makan dari $A$. cerana ini lebih dahulu dibandingkan Apis dorsata dan Apis mellifera. Dengan demikian hal ini menyangkut kepada keefektifan $A$. cerana dalam mencari sumber makanan pada waktu-waktu diatas.

\subsection{Aktivitas harian Apis cerana}

Aktivitas harian pada review ini membicarakan mengenai tarian lebah (bee dancing) sebagai aspek aktivitas di luar sarang dan kualitas madu yang dihasilkan sebagai aspek aktivitas di dalam sarang. Komunikasi tarian lebah madu Apis cerana secara kualitatif mirip dengan Apis mellifera. Namun, pada A. cerana dan kelompok Apidae lainnya yaitu $A$. florea yang mencari makan di tempat makan buatan, tempo tarian diamati menurun (yaitu, waktu per tarian meningkat) lebih cepat daripada yang dilaporkan untuk $A$. mellifera karena jarak ke sumber makanan meningkat. Apis cerana dan A. florea mencari makan jarak pendek; di 3 dari 6 lokasi. A. cerana tidak mengunjungi feeder lebih dari $500 \mathrm{~m}$. Dalam A. dorsata, perubahan tempo tarian dengan bertambahnya jarak ke hijauan jauh lebih lambat dengan yang dilaporkan pada A. mellifera (Punchihewa, R. W. K. et al., 1985).

Tarian lebah ini menyangkut pada foraging ranges yang dimiliki oleh Apis cerana dimana jarak yang ditempuh untuk mencari makanan lebih pendek daripada Apis mellifera. Tarian yang dilakukan dengan waktu lebih singkat disebabkan lebih kepada jarak tempuh yang digunakan oleh lebah pekerja menuju ke sumber makanan lebih pendek sehigga waktu yang digunakan hanya sebentar. Apis cerana tentu memiliki keunikan tersendiri dengan jarak jelajahnya yang pendek dan kemampuannya dalam menemukan sumber makanan.

Terbentuknya madu dalam perut lebah dipengaruhi oleh aktivitas dari mikroorganisme seperti yeast. Madu dari lebah Apis cerana ditinjau dari nilai total yeast tertinggi 7,20 log cfu/g, dan nilai $\mathrm{pH}$ tertinggi sebesar 4,23 terdapat dalam madu lebah Apis mellifera. Madu dari lebah Apis mellifera lebih baik bila ditinjau dari kualitas mikrobiologi dan sifat fisik (Syukrillah, 2018). Pada bagian ini Apis cerana tidak memiliki keunggulan disbanding Apis mellifera namun lebih unggul dari Apis florea dan Apis dorsata. Hal ini tentunya menjadi pertimbangan-pertimbangan dalam memilih Apis cerana sebagai lebah yang akan dibudidayakan terkait bagaimana kelebihan dan keunggulan feeding strategi dan aktivitas harian lebah tersebut.

\section{KESIMPULAN}

Apis cerana memiliki keunikan tersendiri dalam hal strategi mencari makan, aktivitas harian, dan madu yang dihasilkan. Namun, masih ada beberapa aspek yang tidak unggul dimiliki oleh Apis cerana dibandingkan dengan Apidae lainnya. Jenis tumbuhan yang menjadi sumber makanan dari Apis cerana tidak jauh berbeda dari kelompok Apidae lainnya. Foraging ranges atau jarak jelajah dari Apis cerana ini lebih pendek dari yang lainnya, namun jadwal yang digunakan untuk mencari makanan lebih cepat 
karena tidak membutuhkan intensitas cahaya tang tinggi. Dari strategi makan tersebut, muaranya adalah kualitas madu yang dihasilkan dimana Apis cerana masih diungguli oleh Apis mellifera.

\section{DAFTAR PUSTAKA}

Ariandana, R. (2010). Pertumbuhan Benih Ikan Black Ghost (Apteronotus albifrons) pada Intensitas Cahaya dan Lama Penyinaran yang Berbeda. Universitas Lampung.

Ariyanti, E. (2018). Pengaruh Penggunaan Bee Feed Dan Larutan Gula Sebagai Pakan Tambahan Untuk Mempertahankan Koloni Lebah Madu Apis cerana. Universitas Brawijaya.

Beekman, M., \& Ratnieks, F. L. . (2000). Long-Range foraging by the honey-bee, Apis mellifera L. Functional Ecology, 14(4), 490496.

De Lima, D., Lamerkabel, J. S. A., \& Welerubun, I. (2019). Inventarisasi Jenis-Jenis Tanaman Penghasil Nektar Dan Polen Sebagai Pakan Lebah Madu Apis mellifera Di Kecamatan Kairatu Kabupaten Seram Bagian Barat. Agrinimal Jurnal Ilmu Ternak Dan Tanaman, 7(2), 77-82.

Ghosh, S., Chuttong, B., Burgett, M., Meyer-Rochow, V. B., \& Jung, C. (2020). Nutritional value of brood and adult workers of the Asia honeybee species Apis cerana and Apis dorsata. African Edible Insects as Alternative Source of Food, Oil, Protein and Bioactive Components, 21(1), 265-273.
Hasanudi, A. (2014). Panduan Manual Budidaya Lebah Madu. Aek Nuli: Balai penelitian Kehutanan Aek Nuli.

Hidayati, R., Sumarmin, R., \& Wati, M. (2010). Pengaruh Ekstrak Kulit Batang Angsana (Pterocarpus indicus Willd.) terhadap Feeding Strategy Kumbang Koksi (Epilachna punctata Fabricius). Jurnal Ilmiah Mahasiswa STKIP PGRI Sumbar, 2(2), 1-6.

Irsad, I. (2014). Studi Ekologi Apis cerana (Hymenoptera: Apidae) Pada Kebun Campur Di Desa Pagar Puding Kecamatan Tebo Ulu Kabupaten Tebo Provinsi Jambi. Jurnal Mahasiswa STKIP PGRI Sumbar, 1(1), 22-26.

Jasmi, J. (2017). Diversity and blooming season of food sources plant of Apis cerana (Hymenoptera: Apidae) in polyculture plantation in West Sumatra, Indonesia. Biodiversitas Journal of Biological Diversity, 18(1), 3440.

Jayuli, M., Junus, M., \& Nursita, I. W. (2018). Pengaruh Ketingian Terhadap Diameter Polen Lebah Madu (Apis Cerana) Di Kabupaten Malang. Jurnal Ternak Tropika, 19(1), 9-21.

Koetz, A. H. (2013). Ecology, behaviour and control of Apis cerana with a focus on relevance to the Australian incursion. Insects, 4(4), 558-592.

Masnaly, D. C., Wadjdi, M. F., \& Puspitarini, O. R. (2021). Pengaruh Berbagai Ukuran Mangkok Buatan Terhadap Panjang Tubuh Dan Bobot Calon Lebah Ratu Apis cerana java 
genotype. Jurnal Dinamika Rekasatwa, 4(1), 53-56.

Mulyono, M., Susdiyanti, T., \& Supriono, B. (2018). Kajian Ketersediaan Pakan Lebah Madu Lokal (Apis cerana Fabr.). Jurnal Nusa Sylva, 16(2), 18-26.

Novita, N., Saepudin, R., \& Sutriyono. (2013). Analisis Morfometrik Lebah Madu Pekerja Apis cerana Budidaya pada Dua Ketinggian Tempat yang Berbeda. Jurnal Sians Peternakan Indonesia, 8(1), 41-56.

Nudastra, K. E., Artawan, I. K., \& Suryanti, I. A. P. (2016). Studi Preferensi Lebah Madu (Apis cerana) Terhadap Bebagai Jenis Pakan Tambahan Ditinjau Dari Jumlah Kunjungan. Jurnal Pendidikan Biologi Undiksha, 3(2), 1-10.

Pribadi, A. (2018). Karakteristik vegetasi penyusun habitat Lebah Madu Hutan (Apis dorsata. F) di hutan masyarakat Sungai Indragiri Riau. Jurnal Zona, 2(2), 75-80.

Punchihewa, R. W. K., Koeniger, K., Kevan, P. G., \& Gadawski, R. M. (1985). Observations on the dance communication and natural foraging ranges of Apis cerana, Apis dorsata and Apis florea in Sri Lanka. Journal of Apicultural Research, 24(3), 168-175.

Radloff, S. E., Hepburn, C., Hepburn, H. R., Fuchs, S., Hadisoesilo, H., \& Kuznetsov, V. (2010). Population structure and classification of Apis cerana. Apidologie, 41(6), 589-601.

Raju, A., \& Ezardanama, V. (2002). Pollination ecologi and fruiting behaviour in a monocious species, Jatropha curcas L.(Euphorbiaceae). Natural Science: Journal of Science and Technology, 83(1), 1395-1398.

Sarwono, B. (2001). Lebah Madu (ed. Revisi). Jakarta: AgroMedia.

Sembiring, A. K., \& Dinata, M. (2020). Identifikasi Dan Observasi Hama Pada Tanaman Kakao (Theobroma cacao L.) Di Desa Cubadak Kecamatan Lima Kaum Kabupaten Tanah Datar. BioLectura , 5(2),200-205. https://doi.org/10.31849/bl.v5i2. 2155

Syukrillah, M. F. A. (2018). Kualitas Mikrobiologi Dan Sifat Fisik Madu Dengan Nektar Kaliandra Pada Berbagai Lebah Madu Yang Berbeda (Apis Mellifera, Apis Cerana Dan Trigona Sp). Universitas Brawijaya.

Van Rijn, P., Van Houten, Y., \& Sabelis, M. (2002). How plants benefit from providing food to redators even when it is also edible to herbivores. Ecology, 83(10), 2664-2679.

Verma, L. R., \& Dulta, P. . (1986). Foraging behaviour of Apis cerana indica and Apis mellifera in pollinating apple flowers. Journal of Apicultural Research, 25(1), 197-201.

Wibowo, E. P., Syafrizal, S., \& Susanto, D. (2017). Jenis Tumbuhan Sumber Nektar Lebah Apis dorsata Fabr. Dari Desa Bumi Harapan Dan Desa Bukit Raya Kecamatan Sepaku Kalimantan Timur. Bioprospek: Jurnal Ilmiah Biologi, 11(1), 5464. 